\title{
Phenology of Wild and In-vitro Propagated Benguet Lily (Lilium philippinense Baker) Grown in the Greenhouse (BSU Floriculture Project Area, Cabanao, Poblacion, La Trinidad)
}

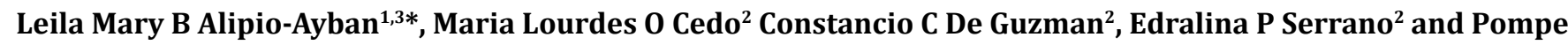 C Sta Cruz ${ }^{2}$}

${ }^{1}$ University of the Philippines Los Baños (UPLB), Laguna, Philippines

${ }^{2}$ Crop Science Cluster, College of Agriculture, University of the Philippines Los Baños, (UPLB), Laguna, Philippines

${ }^{3}$ Benguet State University (BSU), La Trinidad, Benguet, Philippines

*Corresponding Author: Leila Mary B Alipio-Ayban, University of the Philippines Los Baños (UPLB) and Benguet State University (BSU), La Trinidad, Benguet, Philippines.

Received: April 22, 2019; Published: June 13, 2019

DOI: $10.31080 / A S A G .2019 .03 .0527$

\begin{abstract}
Benguet lily (Lilium philippinense) is an endemic lily found in the mountains of the Cordilleras with a high potential of being utilized as cut flower and as potted plant since it has a high resemblance to commercially produced liliums. During the past decade, however, its population continuously declined these prodded the conduct of studies aimed to conserve, domesticate and propagate the plant through tissue culture Unfortunately, the growth and development of Benguet Lily collected from the wild and those that were invitro propagated maintained under greenhouse condition has not been adequately described. The aim of the present study is to evaluate and compare the performance of the wild and the in-vitro propagated Lilium philippinense when both are grown in the greenhouse.

The wild and in-vitro propagated Benguet lily plants exhibited similar growth phases in the greenhouse. The major growth phases include shoot emergence, flower bud emergence, flower opening, capsule emergence, capsule maturation, dehiscence of seeds and plant senescence. The duration of the growth phases and corresponding climatic condition were different for the two types of plants.

Shoot emergence in both plant type coincides with a relatively cooler temperature and humid condition. More humid and warmer temperature favors flower bud emergence in wild plants while cooler and humid condition favors it in-vitro propagated plants. Flower opening of both plant type was favored by cold and more humid condition. Capsule emergence and maturation in wild plants is favored by comparably cold and humid condition while warmer and drier condition favors capsule emergence and maturation in in-vitro propagated plants. The differences observed in the transition and duration of each growth phase between appeared to be highly attributable to the difference in maturity of the planting material used. The high adaptability of L. philippinense to both field and greenhouse conditions points to a high potential for commercialization.
\end{abstract}

Keywords: Phenology; Benguet Lily; Lilium philippinense

\section{Introduction}

Lilium philippinense is a native plant of the mountains of Benguet and nearby Mountain Province, and was first chronicled in 1873. In the 1880's, it was reported that populations of this species occur in clusters of the hundreds. However, years later, the cluster had only 10 to 50 individuals or less [1]. The decline in the population of L. philippinense in the wild was affirmed by Madulid [2] and was attributed to overcollection of farmers and plant hobbyists.
In an effort to save and preserve this species, in-vitro propagation technique was developed by several researchers [36]. Unfortunately, the growth and development of Benguet Lily collected from the wild and those that were in-vitro propagated then maintained under greenhouse condition has not been adequately desribed. The aim of the present study is to evaluate and compare the performance of the wild and the in-vitro propagated Lilium philippinense when both are grown in the greenhouse. 
Phenology of Wild and In-vitro Propagated Benguet Lily (Lilium philippinense Baker) Grown in the Greenhouse (BSU Floriculture Project Area, Cabanao, Poblacion, La Trinidad)

\section{Materials and Methods}

\section{Time and place of study}

The experiment was conducted in May 2015 to June 2016 in the BSU Floriculture Project Area, Cabanao, Poblacion, La Trinidad (Figure $2 \mathrm{a}$ and $\mathrm{b}$ ). It is situated in the inner part of Benguet with geographical coordinates of $16027^{\prime} 18^{\prime \prime}$ north longitude and $120 \mathrm{o}$ $35^{\prime} 15^{\prime \prime}$ east latitude and an elevation range from 500 to $1700 \mathrm{~m}$ above sea level.

\section{Plant selection and management}

One hundred wild Benguet Lily plants at shoot emergence stage were dug-out from their natural habitat on the mountain sides of Moatong, Poblacion, Bokod. They were transplanted to $5 \mathrm{x} 8$ polybags containing Alnus compost as soil medium and were placed in the greenhouse at the BSU Floriculture Project Area. Likewise, one hundred in-vitro propagated plantlets were transplanted to polybags containing the same soil media. These plantlets were regenerated from bulbs that were collected from the natural habitat in Moatong, Poblacion, Bokod and cultured in-vitro from October 2014 to March 2015 using the modified invitro propagation protocol of Ayban [6]. The bagged plants (Figure $1 \mathrm{a}$ and $\mathrm{b}$ ) were maintained in the same greenhouse, and were irrigated three times a week at full saturation level while other cultural practices like weeding were done as needed.

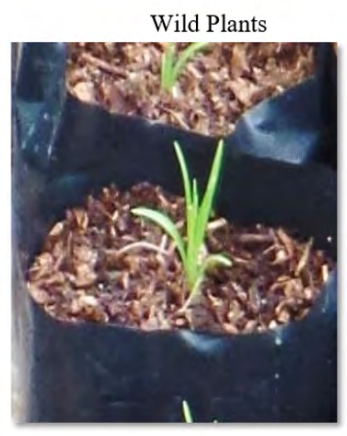

a

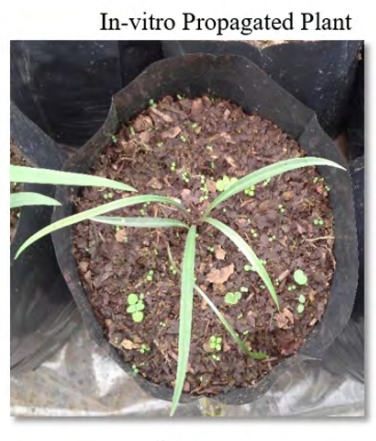

b
Figure 1: Wild (a) and In-vitro propagated (b) L. philippinense in polybags and grown under greenhouse condition in the BSU Floriculture Project Area, Cabanao, Poblacion, La Trinidad.

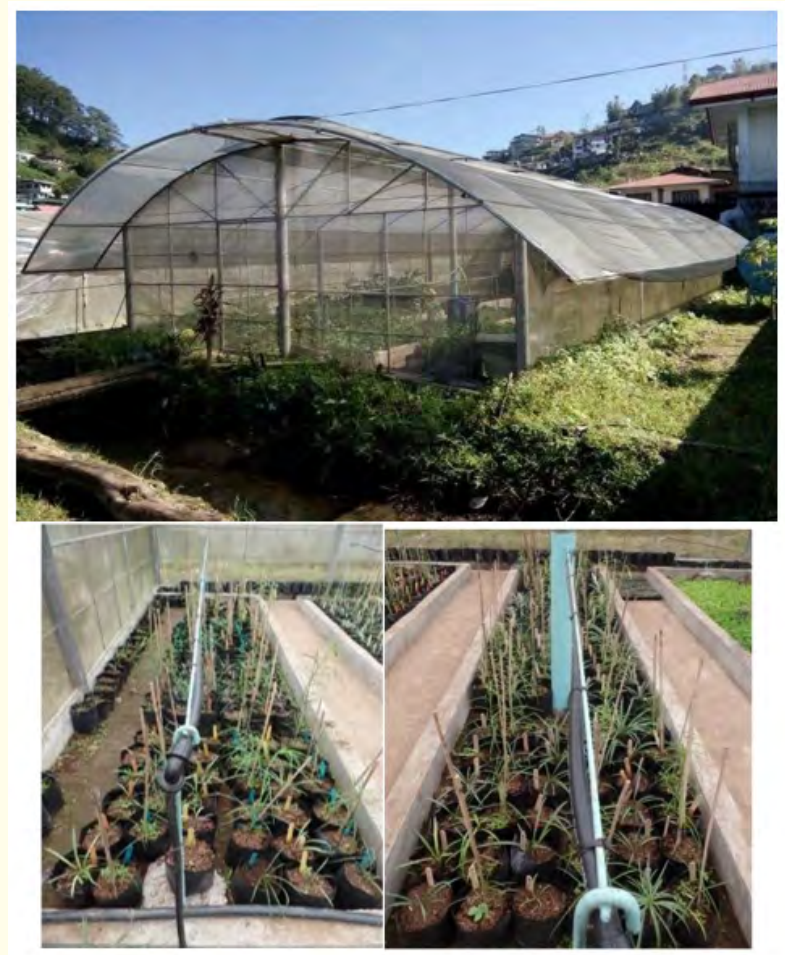

Figure 2: Experimental set-up in BSU Floriculture Project Area at Cabanao, Poblacion, La Trinidad. (a) The greenhouse used in the study. (b) The experimental set up in the greenhouse.

\section{Climatic data}

Daily temperature and relative humidity were taken throughout the study using a generic weather forecaster with built in digital thermometer which records two readings, one at 6:00 in the morning and another at 3:00 in the afternoon. The average of the two readings was taken as the temperature and relative humidity for the day. The daily temperature and relative humidity were averaged to obtain the monthly average temperature and relative humidity, respectively. Daily photoperiod was obtained from the nearest PAG-ASA weather station.

\section{Soil analysis}

Soil samples in this study were obtained in the composite pile of Alnus compost used as a potting media before shoot emergence

Citation: Leila Mary B Alipio-Ayban., et al. "Phenology of Wild and In-vitro Propagated Benguet Lily (Lilium philippinense Baker) Grown in the Greenhouse (BSU Floriculture Project Area, Cabanao, Poblacion, La Trinidad)”. Acta Scientific Agriculture 3.7 (2019): 114-121. 
and after plant senescence. Four samples were brought to the BSU Soil Science Service Laboratory for analysis.

\section{Identification of phenological phases}

One hundred samples each from wild plants and in-vitro propagated plants were observed for the highly distinguishable phenological phases using the modified phenological scale described by Meier [7]. A phase was said to begin when $10 \%$ of the sample plants are in that particular phase, while a phase is said to cease when $10 \%$ of the sample plants are still in that phase. The peak of a phenological phase is when $80 \%$ of the sample plants have reached the phase. The number of days to the different growth phases was determined using the start of shoot emergence as a point of reference.

The phenological phases in both wild and in-vitro propagated plants were plotted against the different climatic data obtained to generate the phenological calendar from shoot emergence during the current season to shoot emergence the following growing season.

\section{Results}

\section{Climatic condition during the growing season}

Daily temperature, relative humidity, and photoperiod were recorded and averaged monthly from May 2015 to June 2016 (Figure 3 and 4) while data from January to April was obtained from the PAG-ASA BSU Weather Station. The lowest temperature (16.230C) was recorded in February 2016 and warmest (22.130C) in April 2016. The highest relative humidity of $93.7 \%$ was observed in August 2015 (Figure 3) while the lowest of 73.59\% was in April 2016. The shortest photoperiod was in December, 11 hours 9 min. while the longest was in June 2015, 13 hours 3 minutes (Figure 4).

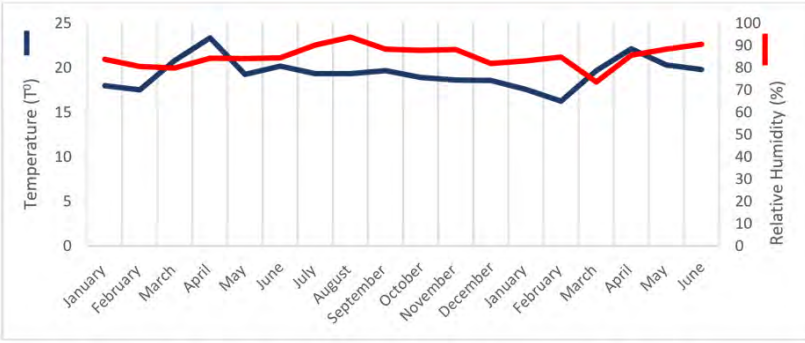

Figure 3: Temperature and relative humidity obtained under greenhouse condition in BSU Floriculture Project Area, Cabanao,

Poblacion, La Trinidad from January 2015 to June 2016 with January to April 2015 as secondary data from PAG-ASA BSU Weather Station.

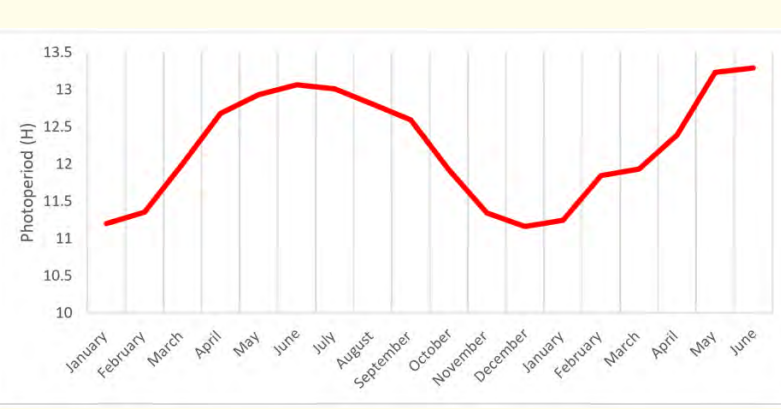

Figure 4: Photoperiod recorded under greenhouse condition in BSU Floriculture Project Area, Cabanao, Poblacion, La Trinidad from January 2015 to June 2016 with January to April 2015 as secondary data from PAG-ASA BSU Weather Station.

La Trinidad belongs under the Type I climate with a distinct wet and dry season.

Dry season is from November to April while the wet season starts from May to October. The average temperature ranges from $11.7^{\circ} \mathrm{C}$ to $23.20 \mathrm{C}$ with an average daily temperature of $18.550 \mathrm{C}$. In the month of December however, temperature dropped to as low as $70 \mathrm{C}$ while the warmest can be as high as $23.2^{\circ} \mathrm{C}$ during the months of March, April, and May. For the duration of the study, there were 198 rainy days with August and September being the rainiest months, while July and December were recorded as the most and least humid months, respectively (www.dilg.car).

Greenhouse cultivation is advantageous because it helps to maintain an optimal plant growth environment and protects the crops from varying outdoor conditions.

However, the values of temperature and relative humidity inside the greenhouse covered with diffusive plastic were very similar to outside conditions, reaching small differences, on average. $1.80 \mathrm{C}$ above the outside temperature ad 4.4\% lower than external $\mathrm{pH}$ [8].

\section{Soil analysis}

Analysis of the Alnus compost used as the bagging medium was done at the Department of Soil Science Service Laboratory of Benguet State University. Results of the analysis are presented in Table 1. After the experiment, the soil became slightly acidic (lower $\mathrm{pH}$ ) while organic matter and available $\mathrm{N}$ were significantly reduced. $\mathrm{P}$ level was almost unchanged while $\mathrm{K}$ increased slightly. The $\mathrm{pH}$ levels recorded at the beginning and end of the study fall within the ranges for both Asiatic and longiflorum hybrid groups [9]. 


\begin{tabular}{|l|c|c|c|c|c|}
\hline & $\begin{array}{c}\text { Soil } \\
\mathbf{P h}\end{array}$ & $\begin{array}{c}\mathbf{O . M} \\
\mathbf{( \% )}\end{array}$ & $\begin{array}{c}\mathbf{N} \\
\mathbf{( p p m )}\end{array}$ & $\begin{array}{c}\mathbf{P} \\
\mathbf{( p p m )}\end{array}$ & $\begin{array}{c}\mathbf{K} \\
\mathbf{( p p m )}\end{array}$ \\
\hline Start of the study & 6.83 & 1.66 & 83 & 20 & 73 \\
\hline End of the study & 6.48 & 0.11 & 50 & 18 & 8.8 \\
\hline
\end{tabular}

Table 1: Analysis of Alnus compost used as a bagging medium for plants grown under greenhouse condition.

Phenology, growth and development of transplanted wild and in-vitro propagated Lilium philippinense in greenhouse condition

The duration in the greenhouse of the different growth phases observed in transplanted wild and acclimatized in-vitro propagated $L$ philippinense plants are presented in Figures 7 and 8. The percentage of plants under the different growth phases is presented in Figure 9. The growth phases observed were (a) shoot emergence, (b) flower bud emergence, (c) flower opening, (d) capsule emergence, (e) capsule maturity, and (f) senescence. Furthermore, differences in the duration and climatic condition of the different growth phases were also observed.

\section{Emergence of the Shoot/New Leaf}

Shoots of transplanted wild L. philippinense emerged in the fourth week of May or 21 DAT. At this time, temperature, relative humidity, and photoperiod were at $19.2^{\circ} \mathrm{C}, 85.2 \%$ and $12 \mathrm{H} 55$ minutes, respectively. After $42 \mathrm{DAT}, 68 \%$ of the plant population had initiated new leaves and the growth phase lasted until the $56^{\text {th }}$ DAT. In contrast, the shoots of in-vitro propagated plants emerged one week later at $28^{\text {th }}$ DAT. On the fourth week of July, $72 \%$ of the in-vitro propagated plants had their leaves unfurled.

Flower bud emergence and development

The flower bud of the wild L. philippinense (Figure 5a) was observed on the third week of June, 35 days after shoot emergence (DASE), during which the average temperature obtained was $20.3^{\circ} \mathrm{C}$ and relative humidity was $84.6 \%$. By 63 DASE, all the transplanted wild L. philippinense had initiated flower buds.

The in-vitro propagated plants, on the other hand, took a longer time to change phase. Flower buds (Figure $5 \mathrm{~b}$ ) started to emerge on the third week of October or 154 DASE, during which the temperature, relative humidity, and photoperiod had decreased to $18.7^{\circ} \mathrm{C}, 87 \%$ and 11 hours 55 minutes. As temperature, relative humidity and photoperiod gradually decreased in the second week of January or 231 DASE, more in-vitro propagated plants initiated flower buds. The slowest plants to develop had their flower buds out by 280 DASE at a temperature of $16.5^{\circ} \mathrm{C}$, relative humidity of $74.8 \%$ and photoperiod 11 hours 10 minutes.
The mature flower buds of wild plants (Figure 5c) open on the second week of July, 21 days after flower bud emergence (DAFBE) where temperature and relative humidity was $89.7 \%$ and $19.4^{\circ} \mathrm{C}$, respectively. More matured flower buds opened at more humid condition of $94.3 \%$ during the second week of August which was 42 DAFBE. Flower opening in wild plants ended at 77 DAFBE (Figure 5e).

Unlike in wild plants, mature flower buds of in-vitro propagated plants (Figure $5 \mathrm{~d}$ ) opened on the third week of November $(21$ DAFBE) where the temperature and relative humidity was $18.7^{\circ} \mathrm{C}$ and $87 \%$, respectively. More flower buds in in-vitro propagated bloomed on the third week of January where temperature further decreased to $17.6^{\circ} \mathrm{C}$ and relative humidity to $80.7 \%$ respectively. Flowers of the remainder of the population opened at 147 DAFBE (Figure 5f).
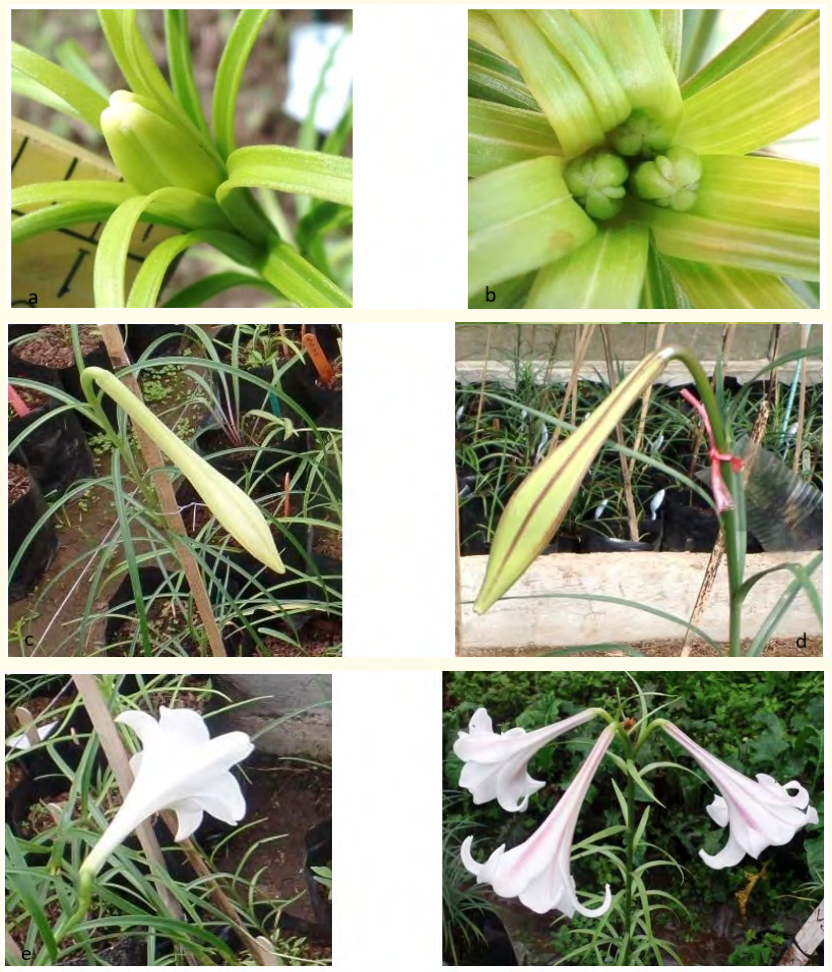

Figure 5: Flowering phase of wild and in-vitro propagated $L$. philippinense under greenhouse condition in BSU Floriculture Project Area in Cabanao, Poblacion, La Trinidad. Flower bud emergence ( $a$ and b), Mature flower bud ( $c$ and d) and Flower opening (e and $\mathrm{f}$ ). 
Capsule emergence and development

Capsule emergence occurs when tepals wilt and fall off. For the wild L. philippinense, initial observations of the flower wilting which marks the start of capsule emergence were on the first week of August, and ended on the fourth week of August at comparable climatic condition to that obtained during the flower opening phase (Figure 6a). On the other hand, tepals of in-vitro propagated L. philippinense started to fall off during the first week of November in which the temperature and relative humidity were down to $18.6^{\circ} \mathrm{C}$ and $83.4 \%$, respectively (Figure 6b). More immature capsules were observed during the second week of February when the temperature was at its coldest at $16.7^{\circ} \mathrm{C}$ and relative humidity decreased to 75 . $8 \%$. As the environment got warmer on the second week of April or 329 DASE, fewer immature capsules were observed.

The onset of capsule maturation in both wild and in-vitro propagated Benguet Lily is marked by the change of color from dark green to lighter green and eventually to light brown. Initial capsule maturation in wild L. philippinense (Figure 6c) was observed 105 DASE during which the recorded average temperature was $19.70 \mathrm{C}$, relative humidity of $90.7 \%$ and photoperiod at 12 hours 25 min. respectively. Capsule maturation peaked during the second week of October where $70 \%$ of the remaining plant populations had reached maturity. At full plant maturity, the capsule splits and releases its seeds while the other upper plant parts wither, marking the beginning of the senescence stage at 140 DASE. On the other hand, the in-vitro propagated L. philippinense capsules was observed to mature 238 DASE on the third week of January when temperature and relative humidity decreased, and photoperiod increased (Figure 6d). As the temperature increases during the second week of April to $22^{\circ} \mathrm{C}$ and relative humidity decreases to $73.9 \%$, the remaining immature capsules of in-vitro propagated matured after 350 DASE.
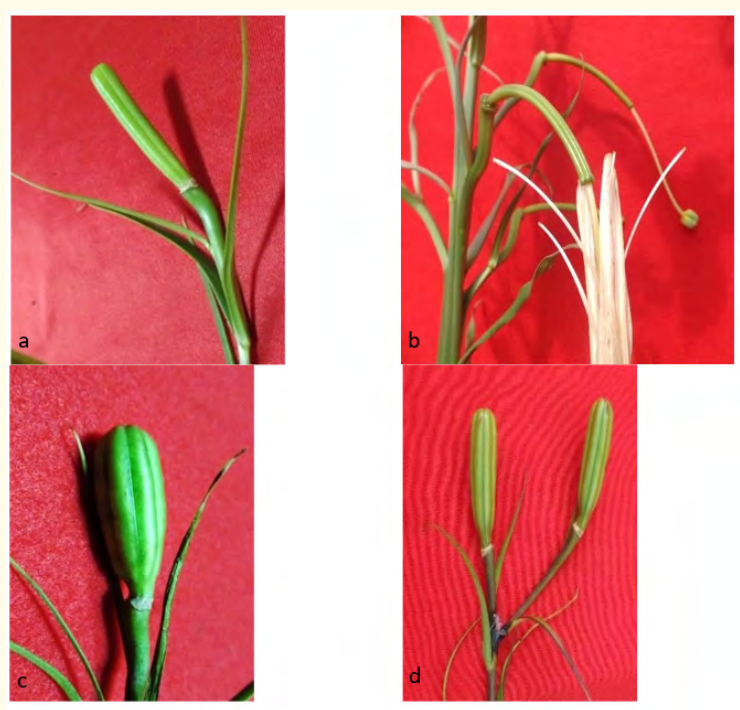

Figure 6: Capsule emergence and maturation phase in wild (a-c) and in-vitro propagated (b-d) L. philippinense grown under greenhouse condition in BSU Floriculture Project Area, Cabanao, Poblacion, La Trinidad, Benguet. Capsule emergence (a-b) and Capsule Maturation (c-d).
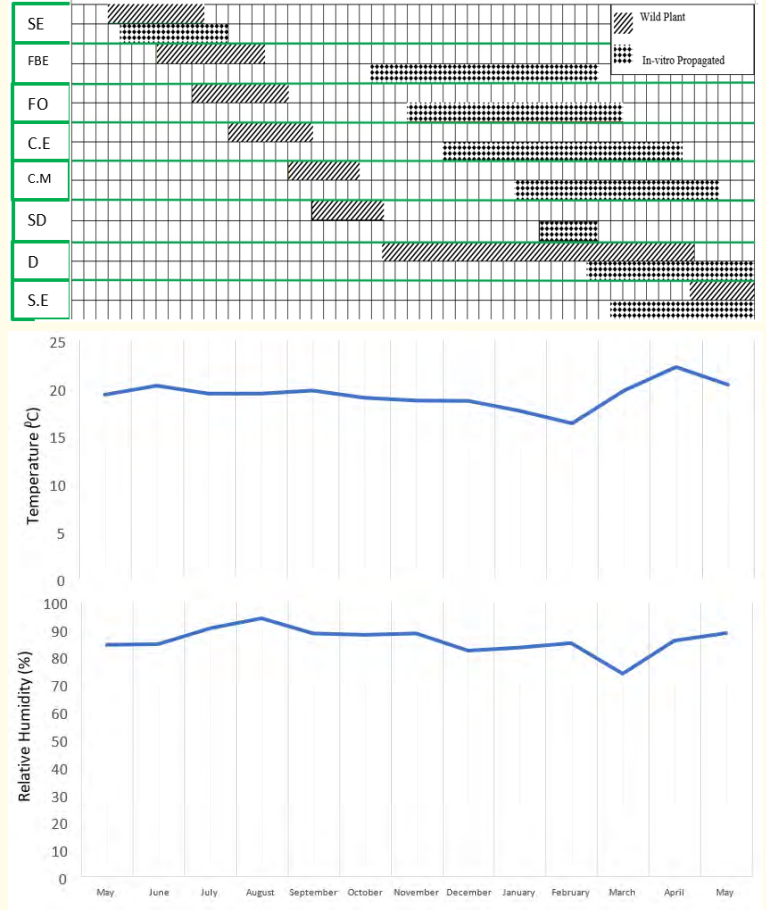

Figure 7: Phenological calendar of wild and in-vitro propagated L. philippinense under greenhouse condition in BSU Floriculture

Project Area, Cabanao, Poblacion, La Trinidad with the corresponding climatic condition. Temperature (a) and Relative humidity (b) S.E- Shoot Emergence; FBE- Flower Bud Emergence; FO- Flower Opening: CE-Capsule.

Emergence; CM - Capsule Maturation; SD Dehiscence of Seeds D- Dormancy

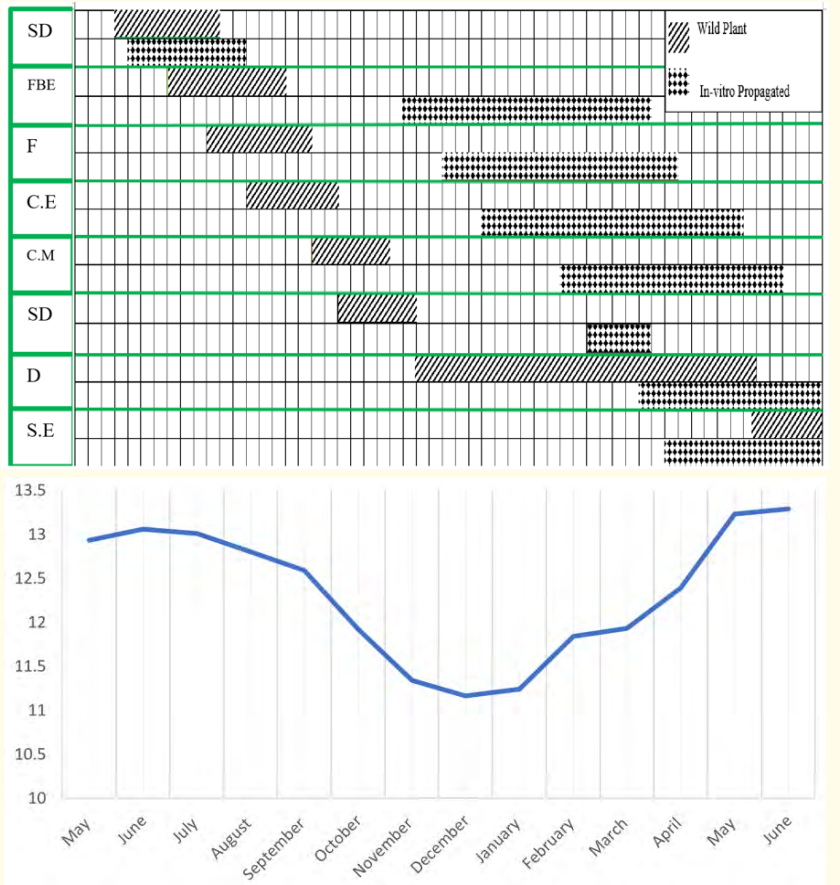

Figure 8: Phenological calendar of wild and in-vitro propagated L. philippinense under greenhouse condition in BSU Floriculture

Project Area, Cabanao, Poblacion, La Trinidad with the corresponding photoperiod. S.E- Shoot Emergence; FBE- Flower Bud Emergence; F- Flower Opening: CE-Capsule Emergence; CM Capsule Maturation; SD- Dehiscence of Seed; D- Dormancy. 


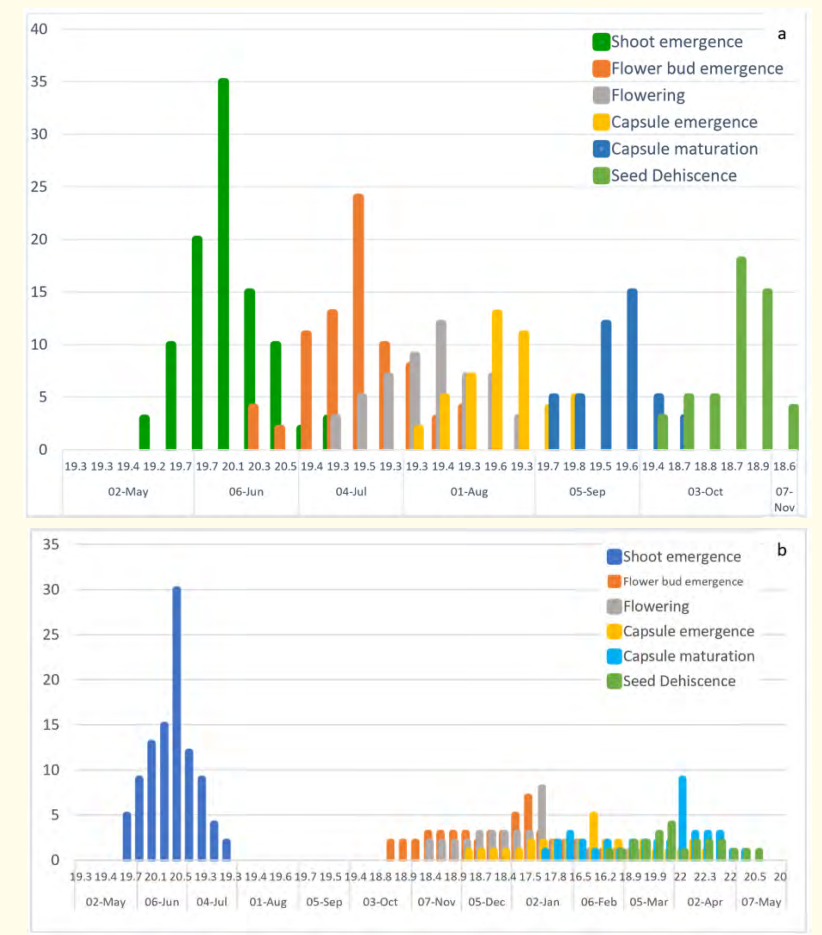

Figure 9: Percentage of plants in the different growth phases at the indicated time and temperature under greenhouse condition

i n BSU Floriculture Project Area in Cabanao, Poblacion, La Trinidad. Wild (a) and In-vitro propagated (b) L. philippinense.

For both plants at capsule maturity, the different plant parts start to wither, and the capsule opens and dehisces the seeds. At this point, the bulb enters the dormancy phase until the next growing season.

\section{Discussion}

In general, La Trinidad has a cold weather condition with relatively low temperatures reaching at a mean average of $15^{\circ} \mathrm{C}$. The average minimum temperature for the last 5 years is at $14.68^{\circ} \mathrm{C}$ and the maximum temperature averaged to $23.6^{\circ} \mathrm{C}$ (latrinidad.gov. ph). During the time of the study, the months of January, February until the first week of March were the coldest, and the warmest were the last week of March and April. La Trinidad falls under Type I climate condition where the rainy season is from May to October and the dry season is from November to April. Thus, highest relative humidity was observed during the months of August with a monthly average of $93 \%$ and the lowest of $84 \%$ observed during the month of April. For photoperiod, longest day was observed during the month of June while the shortest was observed during the month of December.
In this study, the environmental condition inside the greenhouse from May 2015 to June 2016 was monitored daily and averaged to obtain the monthly climatic condition. There was little variation between internal and external conditions during the study. Similar to the external climatic condition, the lowest temperature was obtained in February with an average of $16.230 \mathrm{C}$ and the highest temperature was in April with an average of 230C. De Andrade., et al. [10] reported that climatic conditions inside the greenhouse were $8.5 \%$ higher than the external climatic condition. In addition, Boueri and Lunardi [11] reported that the temperature in a protected environment is $17 \%$ or $3.30 \mathrm{C}$ higher than the outside environment, except for relative humidity, which is lower inside the greenhouse than outside. These variations are mainly dependent on the type of ventilation that is present in the facility.

On the other hand, the lowest relative humidity was obtained in April 2016 with an average of $73.59 \%$ and the highest was in August 2015 with an average of 87.8\%. The longest day was in June 2015 with an average of 13 hours and 3 minutes and shortest day was in December with an average of 11 hours 9 minutes.

The Alnus compost used in the study compares to the recommended soil for growing commercial Lilium species - highly porous with a good water-holding capacity and $\mathrm{pH}$ of 6 to 6.5 [12]. At the start of the experiment, the soil pH was 6.83 (slightly acidic), with $1.66 \%$ of organic matter, $83 \mathrm{ppm}$ of available nitrogen, $20 \mathrm{ppm}$ of phosphorus and $73 \mathrm{ppm}$ of potassium. After the study, a significant decrease in the soil $\mathrm{pH}$ to 6.48 , the organic matter content to $0.11 \%$ and the available NPK decreased to $50 \mathrm{ppm}, 1.8$ ppm and 8.8 ppm, respectively.

Transplanted wild and in-vitro propagated L. philippinense showed similar growth phases, wild L. philippinense in the greenhouse developed earlier compared to in-vitro propagated plants. Wild plants were observed to be well adapted to the cooler temperature $\left(19.2^{\circ} \mathrm{C}\right)$ and more humid condition (90\% RH) in the greenhouse. This high adaptability of L. philippinense to both field and greenhouse conditions points to a high potential for commercialization.

Other factors that affect the growth and development of plants in the greenhouse include temperature, specifically that to which dormant bulbs are exposed and initial bulb weight. Flowering in most Liliums is highly dependent on the exposure of dormant bulbs to low temperature to break dormancy and promote flower initiation [13,14]. Okubo., et al. [15] reported that in Lilium formosanum and Lilium brownii var. colchesterii bulbs that were 
stored at $10^{\circ} \mathrm{C}$ for 4,6 , and 8 weeks and grown in a greenhouse at $12^{\circ} \mathrm{C}$, flowered after 170,138 , and 144 days while untreated bulbs did not flower.

For wild plants grown in the greenhouse, exposure of bulbs to low temperature occurred in the natural habitat during the months of January to February which was four months before they were collected. During that time, average temperature recorded was $19.2^{\circ} \mathrm{C}$ in January and $18.3^{\circ} \mathrm{C}$ in February, which was low enough to break the dormancy and promote flowering in the wild plants. Transplanted wild plants developed flower buds and flowered earlier compared to in-vitro propagated plants wherein both coincided with humid condition.

In-vitro propagated plants had a longer period of growth and development than the wild plants. This is closely attributed to the juvenile state of in-vitro propagated bulblets. Lian., et al. [16] reported that when directly planted, small bulblets produced invitro emerged slowly, were ununiform, and had low survival.

Heavier bulbs tend to produce plants that grow faster and develop earlier than smaller sized bulbs. Langens-Gerrits., et al. [17] specifically mention sufficiently larger bulbs $>300 \mathrm{mg}$ sprouts with a stem instead of a rosette plant. Today, in-vitro bulbs are considered juvenile bulblets that will flower after two to three vegetative growing cycles in the soil, except for Lilium longiflorum which flowers in the first growing season after tissue culture $[17,18]$.

Mojtahedi., et al. [19] observed a longer developmental phase in in-vitro propagated L. longiflorum cv. "Ceb-dazzle" which flowered after 16 months. Misra and Datta [20] observed the same for invitro propagated Asiatic hybrid plantlets that were planted in pots and maintained under field condition. They first formed a rosette of leaves for six months, then the stem became visible only after nearly 16 to 18 months. In addition, in-vitro propagated Allium sativum was observed to have longer vegetative development during the first growing season [21-23].

\section{Conclusion}

Wild and in-vitro propagated L. philippinense exhibited similar growth phase but differs in the duration of each phase. The growth phases observed were shoot emergence, flower bud emergence, flower opening, capsule emergence, capsule maturation, dehiscence of seeds, dormancy and shoot emergence for the following growing year. In terms of duration of the growth phase, in-vitro propagated plants have a longer transition to each phase compared to wild plants that develops earlier.
Shoot emergence in both coincide with a relatively cold warm temperature and humid condition while in flower bud emergence, wild L. philippinense was favored by warmer and humid condition while in in-vitro propagated plants it was favored by humid condition but at a colder condition. Flower opening of both plant type was favored by colder and more humid condition compared during flower bud emergence phase. Capsule emergence and maturation of both occurred at lower climatic condition compared to that obtained during the flower opening.

Results provided a baseline information on the phenology of wild and in-vitro propagated plants under greenhouse condition. Notably, high adaptability of L. philippinense to diverse conditions points to a high potential for commercialization.

\section{Bibliography}

1. Elwes JH. "A monograph of the genus Lilium”. London:Taylor and Francis (1880): 594.

2. Madulid D. "A pictorial cyclopedia of Philippine ornamental plants". 2nd ed. Philippines: Bookmark Inc. (2000): 388.

3. Sevidal Z L. "In-vitro culture of lilium using bulbscale explants". Unpublished B.S. Thesis. Benguet State University (1995).

4. Zamora A B and S S Gruezo. "Shoot Culture and Plant Regeneration in Benguet Lily". Philippine Journal of Crop science 24.2-3 (1999): 85-89.

5. Ampaguey DW., et al. "In-vitro propagation of Benguet lily (Lilium philippinense)”. BS Thesis (unpub). BSU, La Trinidad, Benguet 1.3 (2003): 5-7.

6. Ayban LMA. In-vitro Vegetative Clonal Propagation of Benguet Lily (Lilium philippinense) MS Thesis (unpub). BSU La Trinidad, Benguet. (2011): 1-3.

7. Meier U. "Growth stages of Mono- and Dicotyledonus Plants". BBCH Monograph, Blackwell Wissenschafts-Verlag Berlin Wien (1997).

8. Holcmani E., et al. "Microclimatic Changes by Different Plastic Coverings in Greenhouses Cultivated with Cherry Tomato in Southern Brazil". 1 University of São Paulo, Agricultural College "Luiz de Queiroz" (USP/ESALQ), Department of Biosystems Engineering, Piracicaba/SP, Brazil 2 USP/ESALQ, Department of Crop Science, Piracicaba, SP, Brazil". Revista Brasileira de Meteorologia 30.2 (2015): 125-133.

9. Thangnam M., et al. “Lilium Cutflower Production under Naturally Ventilated Polyhouse. Icar-Central Coastal Agricultural Research Institute". Extension Folder 74 (2016). 
10. De Andrade AS Jr., et al. "Variations in Greenhouse Cultivated with Gerbera and Relationship with External Conditions". Engenharia Agrícola Jaboticabal 31.5 (2011): 857-867.

11. Boueri MA and DMC Lunardi. "Avaliação de elementos agrometeorólogicos no cultivo do cravo-de-defunto (Tagetes sp.) em ambiente protegido e a campo". Revista Energia na Agricultura, Botucatu 21.3 (2006): 45-54.

12. Evans MR and Beck R. "Production of Hybrid and Asiatic Lilies". Production Guide of the University of Florida IFAS Extension (2007).

13. Rabinowitch HD. "Onions and Other Edible Alliums". Handbook of Flowering. Volume I. Boca Raton: CRC Press. (1985): 398-409.

14. De Hertogh AA and MLe Nard. "Botanical aspects of flower bulbs; The Physiology of Flowering Bulbs". Elsevier, Amsterdam, The Netherlands (1993): 7-20.

15. Okubo H., et al. "New Insights into Lilium brownie var. Colchesteri". Floriculture and Ornamental Biotechnology 6.2 (2012): 44-52.

16. Lian M L., et al. "Growth of Lilium Oriental Hybrid 'Casa blanca' bulblet using bioreactor culture". Scientia Horticulturae 97.1 (2003): 41-48.

17. Langen Gerrits M., et al. "Phase Change in Lily Bulblets Regenerated In-vitro”. Physiologia Plantarum 119.4 (2003): 590597.

18. Higgins WS and DP Stimart. "Influence of in Vitro Generation Temperature and Post In-vitro Cold Storage Duration on Growth Response of Lilium longiflorum Bulblets". Journal of the American Society for Horticultural Science 115.6 (1990): 930-933.

19. Mojtahedi N., et al. "Role of Temperature in Dormancy Induction and Release in One-year-old Seedlings of Lilium longiflorum Populations". Journal of the Japanese Society for Horticultural Science 82.1 (2013): 63-68.

20. Misra P and S K Datta. "Acclimatization of Asiatic Hybrid Lilies under Stress Conditions after Propagation through Tissue Culture". Current Science 81.12 (2001): 1530-1533.

21. Metwally E I., et al. "Bulb and Vegetative Characteristics of Garlic (Allium sativum L.) from In vitro Culture through Acclimatization and Field Production". African Journal of Agricultural Research 7.43 (2012): 5792-5795.
22. Balangcod TD. "Autecology of Lilium philippinense". PhD. Dissertation. University of the Philippines Los Banos library. Philippines. (2009): 202.

23. La Trinidad Socio Economic Profile.

\section{Volume 3 Issue 7 July 2019 \\ (C) All rights are reserved by Leila Mary B \\ Alipio-Ayban., et al.}

